\title{
'Shamed' Durban doctor claims ZAR20 million
}

\begin{abstract}
A Durban doctor who was summarily marched out of his hospital in full view of patients and colleagues and later suspended, with his provincial health MEC pillorying him on a departmental website for allegedly refusing to treat a car-crash victim, this June sued his employers for ZAR20 million.

Dr Shaheen Seedat, a senior doctor at Mahatma Gandhi Hospital in Phoenix, issued the letter of demand to the KwaZuluNatal (KZN) Department of Health in midJune after being 'wrongfully' accused of failing to clinically assess a severely injured young man, Riveshan Tandather, aged 19, who was brought to the hospital on 11 July last year. Tandather later died. Seedat was reportedly called over to intervene in a 'signover' dispute between an emergency services staffer and hospital staff. The aggrieved ambulanceman laid the complaint.
\end{abstract}

KZN MEC for health, Sibongiseni Dhlomo, ordered a probe headed by Dr Henry Sunpath, posting on his department's website: 'I am appalled by the manner in which a [man who was] critically injured in a motor vehicle accident was dealt with.' Seedat's suspension was lifted in October after an internal enquiry cleared him. Five witnesses, including three doctors and nurses who were on duty on the day, plus an expert witness, testified. However, the matter was then 'escalated' to the Health Professions Council of South Africa, which Seedat's attorney Mervyn Sigamoney described as 'absurd. He said his client had 'not laid a hand' on the deceased. The internal disciplinary hearing should never have taken place, as there was no case to answer, and had fully exonerated his client. No one in authority had yet apologised to Seedat who suffered hugely negative media exposure that left him a patient pariah. Dr Sunpath (a co-respondent in the civil proceedings) proceeded 'recklessly' against Dr Seedat, 'knowing' he was not the treating doctor. Sigamoney said he suspected that 'another agenda is at play here', and warned that the amount claimed could climb if the authorities continued to play hardball. 'My client's career is compromised and the taxpayer gets punished, he added. Samuel Mkhwanazi, the provincial health department's spokesman, said it was 'government policy not to comment on such matters'. Sigamoney said Dr Seedat was frog-marched out of the hospital, in full view of the public and other professionals.

Chris Bateman

chrisb@hmpg.co.za

S Afr Med J 2016;106(9):848.

DOI:10.7196/SAMJ.2016.v106i9.11334 